\title{
Effect of Different Feeding Regimes on Hematological Profile of Crossbred Cows
}

\author{
M. M. Islam ${ }^{1 *}$, S. V. Shah ${ }^{1}$ and M. M. Pathan ${ }^{2}$ \\ ${ }^{1}$ Department of Livestock Production Management, ${ }^{2}$ Department of Veterinary Physiology \\ and Biochemistry, College of Veterinary Science \& Animal Husbandry, Anand Agricultural \\ University, Anand, Gujarat, India \\ *Corresponding author
}

\section{Keywords}

Feeding regime, Hematological profile, Crossbred cows

\section{Article Info}

Accepted: 12 December 2020 Available Online: 10 January 2021
An experiment was conducted to study the effect of different feeding regimes on hematological profile of crossbred cows. Study was conducted on 18 crossbred cows which were distributed into three treatment groups comprising of 6 animals in each group. Animals of $T_{1}$ (Farmers' feeding) group were maintained as per the feeding regime followed by small and marginal farmers. Animals of $T_{2}$ (Modified feeding) group comprised of feeding with scientific interventions with resources available with farmers. Animals of $\mathrm{T}_{3}$ (Farm feeding) group were fed as per feeding followed at Livestock Research Station. Average WBC count $\left(10^{3} / \mu \mathrm{L}\right)$ was significantly $(\mathrm{p}<0.05)$ more in $\mathrm{T}_{3}$ $(7.98 \pm 0.12)$ as compared to $\mathrm{T}_{1}(7.43 \pm 0.17)$ and $\mathrm{T}_{2}(7.52 \pm 0.17)$ groups. Lymphocyte $\left(10^{3} / \mu \mathrm{L}\right)$ was maximum in $\mathrm{T}_{3}(3.32 \pm 0.07)$, followed by $\mathrm{T}_{1}(3.24 \pm 0.10)$ and $\mathrm{T}_{2}(3.12 \pm 0.09)$ group but there was no significant difference among treatment groups. Average monocyte $\left(10^{3} / \mu \mathrm{L}\right)$ level was significantly higher in $\mathrm{T}_{3}(0.61 \pm 0.01)$ when compared with $\mathrm{T}_{1}$ $(0.57 \pm 0.01)$ and $\mathrm{T}_{2}(0.56 \pm 0.01)$ groups. Granulocyte $\left(10^{3} / \mu \mathrm{L}\right)$ was significantly $(\mathrm{p}<0.05)$ higher in $\mathrm{T}_{3}(4.05 \pm 0.10)$ as compared to $\mathrm{T}_{1}(3.62 \pm 0.11)$ group. However, the value of $\mathrm{T}_{2}$ (3.85 \pm 0.12$)$ group was at par with $\mathrm{T}_{1}$ and $\mathrm{T}_{3}$ groups. Average $\mathrm{RBC}\left(10^{6} / \mu \mathrm{L}\right)$ was significantly $(\mathrm{p}<0.05)$ more in $\mathrm{T}_{3}(6.69 \pm 0.08)$ in comparison to $\mathrm{T}_{2}(6.35 \pm 0.07)$ group, whereas, the value of $\mathrm{T}_{1}(6.50 \pm 0.07)$ group was at par with $\mathrm{T}_{2}$ and $\mathrm{T}_{3}$ groups. $\mathrm{Hb}(\mathrm{g} / \mathrm{dL})$ was significantly $(\mathrm{p}<0.05)$ higher in $\mathrm{T}_{3}(10.54 \pm 0.10)$ as compared to $\mathrm{T}_{1}(9.50 \pm 0.08)$ and $\mathrm{T}_{2}$ $(9.62 \pm 0.10)$ groups. Average PCV $(\%)$ was significantly $(\mathrm{p}<0.05)$ higher in $\mathrm{T}_{3}$ $(33.71 \pm 0.32)$ when compared with $\mathrm{T}_{1}(30.04 \pm 0.27)$ and $\mathrm{T}_{2}(30.56 \pm 0.35)$ groups. MCV was $46.73 \pm 0.42,48.32 \pm 0.38$ and $50.77 \pm 0.32 \mathrm{fL}$ in $\mathrm{T}_{1}, \mathrm{~T}_{2}$ and $\mathrm{T}_{3}$ groups, respectively which differed significantly $(\mathrm{p}<0.05)$ among each other. Average of $\mathrm{MCH}$ was $14.80 \pm 0.17$, $15.30 \pm 0.13$ and $15.77 \pm 0.08 \mathrm{pg}$ in $\mathrm{T}_{1}, \mathrm{~T}_{2}$ and $\mathrm{T}_{3}$ groups, respectively which also differed significantly $(\mathrm{p}<0.05)$ among each other. MCHC was $31.63 \pm 0.15,31.52 \pm 0.12$ and $31.22 \pm 0.11 \mathrm{~g} / \mathrm{dL}$ in $\mathrm{T}_{1}, \mathrm{~T}_{2}$ and $\mathrm{T}_{3}$ groups, respectively which did not differ significantly among each other. It may be concluded from the present study that WBC, Monocyte, $\mathrm{Hb}$, PCV, MCH and MCHC were significantly $(\mathrm{p}<0.05)$ more in $\mathrm{T}_{3}$ as compared to $\mathrm{T}_{1}$ and $\mathrm{T}_{2}$ groups, whereas all the parameters except $\mathrm{MCV}$ and $\mathrm{MCH}$ in $\mathrm{T}_{1}$ and $\mathrm{T}_{2}$ group were at par which shows that modified feeding did not influence hematological profile. Although the health of animals was at par in all treatment groups, production and reproduction performance was different among the treatment groups. 


\section{Introduction}

More than $70 \%$ of expenditure in dairy farming is on feeding of animals in developing countries like India (Singh et. al., 2003) and other third world countries. In field conditions, most of the animals are underfed as the poor and illiterate farmers are not aware of the benefits of quality feeding (Khan et al., 2004) and non-availability of required quantity of feed. The success of livestock farming greatly depends on the continuous supply of good quality balanced feed (Suharyono et al., 2018).

Haematological profile of blood is a good indicator of health of the cows (Coroian et al., 2017). Not solely, but in combination with clinical examination or other diagnostic procedures, hematology is highly informative as a diagnostic tool in bovine medicine (Roland et al., 2014). Nutrition is the main technological factor that can produce profound changes in the metabolic profile in animals (Khaled et al., 1999; Ingvartsen, 2006). Haematological parameters reflect adaptability of cows to adverse environmental conditions, as well as other stressors. Haematological profile within normal physiological limits reflects a good health status and is highly correlated with milk production (Coroian et al., 2017). Blood analysis can identify if there are errors in nutrition of lactating cows (Payne et al., 1970).

\section{Materials and Methods}

This experiment was conducted at Livestock Research Station (LRS), College of Veterinary Science and Animal Husbandry, Anand Agricultural University, Anand, Gujarat, India. The study was conducted on 18 dry pregnant HF $\mathrm{x}$ Kankrej (50:50) crossbred cow which were distributed in to three treatment groups of 6 animals in each group. Experimental animals were randomly selected on the basis of first lactation milk (300 d) yield, calving sequence (parity) and body weight $(\mathrm{kg})$ in cronology. The experiment was conducted from $45 \mathrm{~d}$ prepartum (advance pregnancy) to $300 \mathrm{~d}$ postpartum.

Animals of $\mathrm{T}_{1}$ (Farmer's feeding) group were maintained as per the feeding regime followed by small and marginal farmers. Concentrate feed was not given during prepartum period and fed @ 50\% of milk production in the lactation period. Animals were devoid of mineral mixture and fed with paddy/wheat straw on ad lib. basis and 10 $\mathrm{kg} / \mathrm{animal} / \mathrm{d}$ cereal green fodder. Animals of $\mathrm{T}_{2}$ (Modified feeding) group comprised of feeding with scientific interventions with resources available with farmers. Animals were provided concentrate feed @1 $\mathrm{kg} /$ animal/d during pre-partum and @ 50\% of milk production in lactation period. Mineral mixture was provided to animals @ 30 g/animal/d. Legume straw and paddy/wheat straw (50:50 ratio) was given to animals on ad lib. basis and $10 \mathrm{~kg} / \mathrm{animal} / \mathrm{d}$ cereal green fodder was given to the animals. Animals of $\mathrm{T}_{3}$ (Farm feeding) group were fed as per standard feeding followed at LRS. Concentrate feed was given for steaming up in pre-partum period starting from 500 $\mathrm{g} /$ animal/d in the first week of experiment and increasing by $500 \mathrm{~g}$ every week, reaching 3.5 $4.0 \mathrm{~kg} / \mathrm{animal} / \mathrm{d}$ till parturition. During lactation period concentrate feed was given @ $40 \%$ of milk production plus $1 \mathrm{~kg}$ maintenance/animal/d. Animals were fed with $50 \mathrm{~g} / \mathrm{animal} / \mathrm{d}$ mineral mixture. Jowar hay was fed to animals on ad lib. basis and 10 $\mathrm{kg} / \mathrm{animal} / \mathrm{d}$ cereal green fodder was fed to the animals.

Considering the gestation period of $277 \mathrm{~d}$ and the day of calving as day zero in crossbred cattle maintained at Livestock Research 
Station, the following pattern was followed for blood collection--42, $-28,-14,-7,-3,0$, $+3,+7,+14,+21,+28,+35 d$ likewise at every $14 d$ interval till 180 days of lactation and at every 30 days from 180 to 300 days of lactation.

Five to six ml of blood was collected from the jugular vein from each experimental animal in a vaccutainer containing $\mathrm{K}_{3}$ EDTA. Immediately after collection of blood, hematological parameters viz., White Blood Cells (WBC), DLC (Lymphocyte, Monocyte and Granulocyte), Red Blood Cells (RBC), Haemoglobin $(\mathrm{Hb})$, Packed Cell Volume (PCV), Mean Corpuscular Volume (MCV), Mean Corpuscular Hemoglobin (MCH), Mean Corpuscular Hemoglobin Concentration (MCHC) were estimated from fresh blood using blood auto analyzer (BC-2800 Vet, Mindray).

\section{Statistical analysis}

Observations of various hematological parameters recorded during the experimental period were statistically analyzed by Completely Randomized Design (Factorial) using SAS software 9.3 version.

\section{Results and Discussion}

\section{Feed and nutrient intake}

Results of feed and nutrient intake are presented in Table 1. Average fortnightly DMI either $\mathrm{kg} / \mathrm{animal} / \mathrm{d}$ or $\mathrm{kg} / 100 \mathrm{~kg}$ b.wt. was significantly $(\mathrm{p}<0.05)$ more in $\mathrm{T}_{2}$ $(12.45 \pm 0.28$ and $2.74 \pm 0.06)$ and $\mathrm{T}_{3}$ (12.62 \pm 0.22 and $2.81 \pm 0.06)$ as compared to $\mathrm{T}_{1}(9.71 \pm 0.20$ and $2.24 \pm 0.05)$ group. Average fortnightly DCPI (g/animal/d) was significantly $\quad(\mathrm{p}<0.05)$ more in $\mathrm{T}_{2}$ $(801.87 \pm 22.30)$ and $\mathrm{T}_{3}(839.53 \pm 16.63)$ as compared to $\mathrm{T}_{1}(543.83 \pm 14.83)$ group. Average DCPI (g/100kg b.wt.) was
$128.49 \pm 4.51,177.40 \pm 5.00$ and $187.84 \pm 4.51 \mathrm{~g}$ in $\mathrm{T}_{1}, \mathrm{~T}_{2}$ and $\mathrm{T}_{3}$ groups, respectively which differed significantly $(\mathrm{p}<0.05)$ among each other. Average fortnightly TDNI either $\mathrm{kg} / \mathrm{animal} / \mathrm{d}$ or $\mathrm{kg} / 100 \mathrm{~kg}$ b.wt. was significantly $(\mathrm{p}<0.05)$ more in $\mathrm{T}_{2}(7.13 \pm 0.16$ and $1.57 \pm 0.04)$ and $\mathrm{T}_{3} \quad(7.30 \pm 0.13$ and $1.63 \pm 0.04)$ when compared with $\mathrm{T}_{1}$ $(4.82 \pm 0.10$ and $1.11 \pm 0.03)$ group.

\section{Hematological profile}

Results of hematological profile are presented in Table 2. Average WBC count of experimental animals at the beginning of experiment was $8.75 \pm 1.14,7.75 \pm 0.62$ and $7.52 \pm 0.5410^{3} / \mu \mathrm{L}$ in $\mathrm{T}_{1}, \mathrm{~T}_{2}$ and $\mathrm{T}_{3}$ groups, respectively. With the advancement of pregnancy, WBC level gradually increased in all treatment groups and reached maximum on the day of parturition. Average WBC count on the day of parturition was $9.47 \pm 2.08$, $9.63 \pm 1.53$ and $9.68 \pm 0.8510^{3} / \mu \mathrm{L}$ in $\mathrm{T}_{1}, \mathrm{~T}_{2}$ and $\mathrm{T}_{3}$ groups, respectively. After parturition WBC count decreased suddenly on $3^{\text {rd }} \mathrm{d}$ of experiment and then maintained at that level throughout experimental period. Irrespective of periods, average WBC count $\left(10^{3} / \mu \mathrm{L}\right)$ was significantly $(\mathrm{p}<0.05)$ more in $\mathrm{T}_{3}(7.98 \pm 0.12)$ as compared to $\mathrm{T}_{1}(7.43 \pm 0.17)$ and $\mathrm{T}_{2}$ (7.52 \pm 0.17$)$ groups.

Average lymphocyte of experimental animals at the beginning of experiment was $4.38 \pm 0.43,3.88 \pm 0.44$ and $3.58 \pm 0.3810^{3} / \mu \mathrm{L}$, respectively in $T_{1}, \quad T_{2}$ and $T_{3}$ groups. Gradually lymphocyte decreased in all treatment groups and reached very low level on the day of parturition i.e. 2.66 \pm 0.58 , $2.70 \pm 0.16$ and $3.00 \pm 0.5310^{3} / \mu \mathrm{L}$ in $\mathrm{T}_{1}, \mathrm{~T}_{2}$ and $\mathrm{T}_{3}$ groups, respectively. After parturition lymphocyte gradually increased in all treatment groups and maintained at higher level throughout experiment. Overall average lymphocyte $\left(10^{3} / \mu \mathrm{L}\right)$ was maximum in $\mathrm{T}_{3}$ (3.32 \pm 0.07$)$, followed by $\mathrm{T}_{1}(3.24 \pm 0.10)$ and 
$\mathrm{T}_{2}(3.12 \pm 0.09)$ groups but there was no significant difference among them.

Average monocyte of experimental animals at the beginning of experiment was $0.67 \pm 0.10$, $0.60 \pm 0.06$ and $0.62 \pm 0.0610^{3} / \mu \mathrm{L}$ in $\mathrm{T}_{1}, \mathrm{~T}_{2}$ and $\mathrm{T}_{3}$ groups, respectively. Gradually monocyte decreased in all treatment groups during prepartum period and again increased to $0.68 \pm 0.14,0.63 \pm 0.10$ and $0.72 \pm 0.1010^{3} / \mu \mathrm{L}$ in $T_{1}, T_{2}$ and $T_{3}$ groups, respectively on the day of parturition. During postpartum period monocyte level maintained at lower level than that of parturition day. Irrespective of periods, average monocyte $\left(10^{3} / \mu \mathrm{L}\right)$ level was significantly higher in $\mathrm{T}_{3}(0.61 \pm 0.01)$ as compared to $\mathrm{T}_{1}(0.57 \pm 0.01)$ and $\mathrm{T}_{2}$ $(0.56 \pm 0.01)$ groups.

Average granulocyte of experimental animals at the beginning of experiment was $3.70 \pm 0.66,3.27 \pm 0.27$ and $3.32 \pm 0.3010^{3} / \mu \mathrm{L}$ in $\mathrm{T}_{1}, \mathrm{~T}_{2}$ and $\mathrm{T}_{3}$ groups, respectively. Granulocyte increased gradually during prepartum period and reached to $6.13 \pm 1.44$, $6.30 \pm 1.34$ and $5.97 \pm 0.5010^{3} / \mu \mathrm{L}$ in $\mathrm{T}_{1}, \mathrm{~T}_{2}$ and $\mathrm{T}_{3}$ groups, respectively on the day of parturition. After parturition, there was sudden drop in granulocyte and maintained at lower level throughout lactation period. Regardless of periods, average granulocyte $\left(10^{3} / \mu \mathrm{L}\right)$ was significantly $(\mathrm{p}<0.05)$ higher in $\mathrm{T}_{3}(4.05 \pm 0.10)$ as compared to $\mathrm{T}_{1}(3.62 \pm 0.11)$ group. However, the value of $\mathrm{T}_{2}(3.85 \pm 0.12)$ group was at par with $\mathrm{T}_{1}$ and $\mathrm{T}_{3}$ groups.

Average RBC count of experimental animals at the beginning of experiment was $7.09 \pm 0.37,6.79 \pm 0.30$ and $6.99 \pm 0.4410 \% / \mu \mathrm{L}$ in $T_{1}, T_{2}$ and $T_{3}$ groups, respectively. $R B C$ count remained more or less in same range till parturition and after that it declined for 3-4 weeks postpartum and then maintained at lower level throughout lactation period. Irrespective of periods, average $\mathrm{RBC}\left(10^{6} / \mu \mathrm{L}\right)$ was significantly $(\mathrm{p}<0.05)$ more in $\mathrm{T}_{3}$
(6.69 \pm 0.08$)$ when compared with $\mathrm{T}_{2}$ $(6.35 \pm 0.07)$ group. However, the value of $\mathrm{T}_{1}$ $\left(6.50 \pm 0.0710^{6} / \mu \mathrm{L}\right)$ group was at par with $\mathrm{T}_{2}$ and $\mathrm{T}_{3}$ groups.

Average $\mathrm{Hb}$ of experimental animals at the beginning of experiment was $10.95 \pm 0.34$, $10.92 \pm 0.26$ and $11.27 \pm 0.51 \mathrm{~g} / \mathrm{dL}$ in $\mathrm{T}_{1}, \mathrm{~T}_{2}$ and $\mathrm{T}_{3}$ groups, respectively. During pre-partum period, $\mathrm{Hb}$ level continuously decreased in $\mathrm{T}_{1}$ and $\mathrm{T}_{2}$ groups till $3 \mathrm{~d}$ before parturition and increased on the day of parturition. While in case of $\mathrm{T}_{3}$ group $\mathrm{Hb}$ was maintained almost at same level till parturition. Average $\mathrm{Hb}$ was $10.60 \pm 0.33,11.03 \pm 0.46$ and $11.08 \pm 0.34 \mathrm{~g} / \mathrm{dL}$ in $T_{1}, T_{2}$ and $T_{3}$ groups, respectively on the day of parturition. Regardless of periods, average of $\mathrm{Hb}(\mathrm{g} / \mathrm{dL})$ was significantly $(\mathrm{p}<0.05)$ higher in $\mathrm{T}_{3} \quad(10.54 \pm 0.10)$ in comparison to $\mathrm{T}_{1}(9.50 \pm 0.08)$ and $\mathrm{T}_{2}$ (9.62 \pm 0.10$)$ groups.

Average PCV of experimental animals at the beginning of experiment was $34.82 \pm 1.10$, $35.27 \pm 1.16$ and $36.12 \pm 1.46 \%$ in $\mathrm{T}_{1}, \mathrm{~T}_{2}$ and $\mathrm{T}_{3}$ groups, respectively. In $T_{1}$ and $T_{2}$ groups, PCV level decreased during pre-partum period and again increased on the day of parturition. After parturition again it started declining and remained throughout lactation at lower levels. In $\mathrm{T}_{3}$ group, $\mathrm{PCV}$ level was maintained without any decline during prepartum period and after parturition started declining but remained at higher levels as compared to other two groups. Irrespective of periods, average PCV (\%) was significantly $(\mathrm{p}<0.05)$ higher in $\mathrm{T}_{3} \quad(33.71 \pm 0.32)$ as compared to $\mathrm{T}_{1}(30.04 \pm 0.27)$ and $\mathrm{T}_{2}$ $(30.56 \pm 0.35)$ groups.

Average MCV of animals at the beginning of experiment was $49.63 \pm 2.19,52.27 \pm 1.75$ and $52.27 \pm 1.42 \mathrm{fL}$ in $\mathrm{T}_{1}, \mathrm{~T}_{2}$ and $\mathrm{T}_{3}$ groups, respectively. MCV was maintained at the same level till parturition in $\mathrm{T}_{1}$ and $\mathrm{T}_{2}$ groups while in case of $\mathrm{T}_{3}$ group an increasing trend 
was seen till $3^{\text {rd }}$ d postpartum. After that there was a declining trend seen in all treatment groups with advancement of lactation. Irrespective of periods, average $\mathrm{MCV}$ was $46.73 \pm 0.42,48.32 \pm 0.38$ and $50.77 \pm 0.32 \mathrm{fL}$ in $\mathrm{T}_{1}, \mathrm{~T}_{2}$ and $\mathrm{T}_{3}$ groups, respectively and differ significantly $(p<0.05)$ among each other.

Average $\mathrm{MCH}$ of experimental animals at the beginning of experiment was $15.52 \pm 0.56$,
$16.12 \pm 0.40$ and $16.17 \pm 0.31 \mathrm{pg}$ in $\mathrm{T}_{1}, \mathrm{~T}_{2}$ and $\mathrm{T}_{3}$ groups, respectively. During pre-partum period there was no decline in $\mathrm{MCH}$ value but started decreasing and maintained at slightly lower level during post-partum period in all treatment groups. Regardless of periods, average of $\mathrm{MCH}$ was $14.80 \pm 0.17,15.30 \pm 0.13$ and $15.77 \pm 0.08 \mathrm{pg}$ in $\mathrm{T}_{1}, \mathrm{~T}_{2}$ and $\mathrm{T}_{3}$ groups, respectively which differ significantly $(p<0.05)$ among each other.

Table.1 Average feed and nutrient intake of crossbred cows during the experiment

\begin{tabular}{|c|c|c|c|}
\hline \multirow{2}{*}{ Parameters } & \multicolumn{3}{|c|}{ Treatments } \\
\cline { 2 - 4 } & $\mathbf{T}_{\mathbf{1}}$ & $\mathbf{T}_{\mathbf{2}}$ & $\mathbf{T}_{\mathbf{3}}$ \\
\hline DMI (kg/animal/d) & $9.71^{\mathrm{a}} \pm 0.20$ & $12.45^{\mathrm{b}} \pm 0.28$ & $12.62^{\mathrm{b}} \pm 0.22$ \\
\hline DMI (kg/100kg b.wt.) & $2.24^{\mathrm{a}} \pm 0.05$ & $2.74^{\mathrm{b}} \pm 0.06$ & $2.81^{\mathrm{b}} \pm 0.06$ \\
\hline DCPI (g/animal/d) & $543.83^{\mathrm{a}} \pm 14.83$ & $801.87^{\mathrm{b}} \pm 22.30$ & $839.53^{\mathrm{b}} \pm 16.63$ \\
\hline DCPI (g/100kg b.wt.) & $128.49^{\mathrm{a}} \pm 4.51$ & $177.40^{\mathrm{b}} \pm 5.00$ & $187.84^{\mathrm{c}} \pm 4.51$ \\
\hline TDNI (kg/animal/d) & $4.82^{\mathrm{a}} \pm 0.10$ & $7.13^{\mathrm{b}} \pm 0.16$ & $7.30^{\mathrm{b}} \pm 0.13$ \\
\hline TDNI (kg/100 kg b.wt.) & $1.11^{\mathrm{a}} \pm 0.03$ & $1.57^{\mathrm{b}} \pm 0.04$ & $1.63^{\mathrm{b}} \pm 0.04$ \\
\hline
\end{tabular}

Means with dissimilar superscripts in a row differed significantly $(\mathrm{p}<0.05)$

Table.2 Average hematological profile of crossbred cows during experiment

\begin{tabular}{|c|c|c|c|}
\hline \multirow{2}{*}{ Parameters } & \multicolumn{3}{|c|}{ Treatments } \\
\cline { 2 - 4 } & $\mathbf{T}_{\mathbf{1}}$ & $\mathbf{T}_{\mathbf{2}}$ & $\mathbf{T}_{\mathbf{3}}$ \\
\hline WBC $(\mathbf{1 0} \boldsymbol{3} / \boldsymbol{\mu L})$ & $7.43^{\mathrm{a}} \pm 0.17$ & $7.52^{\mathrm{a}} \pm 0.17$ & $7.98^{\mathrm{b}} \pm 0.12$ \\
\hline Lymphocyte $(\mathbf{1 0} / \boldsymbol{\mu L})$ & $3.24 \pm 0.10$ & $3.12 \pm 0.09$ & $3.32 \pm 0.07$ \\
\hline Monocyte $(\mathbf{1 0} / \boldsymbol{\mu} \mathbf{L})$ & $0.57^{\mathrm{a}} \pm 0.01$ & $0.56^{\mathrm{a}} \pm 0.01$ & $0.61^{\mathrm{b}} \pm 0.01$ \\
\hline Granulocyte $\left(\mathbf{1 0}^{\mathbf{3}} / \boldsymbol{\mu L}\right)$ & $3.62^{\mathrm{a}} \pm 0.11$ & $3.85^{\mathrm{ab}} \pm 0.12$ & $4.05^{\mathrm{b}} \pm 0.10$ \\
\hline RBC $(\mathbf{1 0} / \boldsymbol{\mu L})$ & $6.50^{\mathrm{ab}} \pm 0.07$ & $6.35^{\mathrm{a}} \pm 0.07$ & $6.69^{\mathrm{b}} \pm 0.08$ \\
\hline Hb $(\mathbf{g} / \mathbf{d L})$ & $9.50^{\mathrm{a}} \pm 0.08$ & $9.62^{\mathrm{a}} \pm 0.10$ & $10.54^{\mathrm{b}} \pm 0.10$ \\
\hline PCV $(\mathbf{\%})$ & $30.04^{\mathrm{a}} \pm 0.27$ & $30.56^{\mathrm{a}} \pm 0.35$ & $33.71^{\mathrm{b}} \pm 0.32$ \\
\hline MCV (fL) & $46.73^{\mathrm{a}} \pm 0.42$ & $48.32^{\mathrm{b}} \pm 0.38$ & $50.77^{\mathrm{c}} \pm 0.32$ \\
\hline MCH $(\mathbf{p g})$ & $14.80^{\mathrm{a}} \pm 0.17$ & $15.30^{\mathrm{b}} \pm 0.13$ & $15.77^{\mathrm{c}} \pm 0.08$ \\
\hline MCHC $(\mathbf{g} / \mathbf{d L})$ & $31.63 \pm 0.15$ & $31.52 \pm 0.12$ & $31.22 \pm 0.11$ \\
\hline
\end{tabular}

Means with dissimilar superscripts in a row differed significantly $(\mathrm{p}<0.05)$

Average $\mathrm{MCHC}$ in $\mathrm{T}_{1}, \mathrm{~T}_{2}$ and $\mathrm{T}_{3}$ groups at the beginning of experiment was $31.43 \pm 0.37$, $30.97 \pm 0.41$ and $31.05 \pm 0.39 \mathrm{~g} / \mathrm{dL}$, respectively. On the day of parturition little lower value of $\mathrm{MCHC}$ was recorded in all treatment groups which further remained in increasing trend during later part of the lactation period. Regardless of periods, average MCHC was $31.63 \pm 0.15,31.52 \pm 0.12$ and $31.22 \pm 0.11 \mathrm{~g} / \mathrm{dL}$ in $\mathrm{T}_{1}, \mathrm{~T}_{2}$ and $\mathrm{T}_{3}$ groups, respectively which did not differ significantly among each other. 
Results of WBC count in the present experiment are in agreement with the study of Ate et al., (2009) who observed that mean values of WBC during third trimester of pregnancy and early lactation were nonsignificantly different. In present study also difference in WBC count during pre-partum and postpartum period was found nonsignificant. WBC count in the present experiment increased to maximum value on the day of calving irrespective of treatment groups which might be due to anti-partum rise in cortisol level (Hussain and Daniel, 1992). After parturition sudden decrease in WBC count was seen in present study which is associated with its migration toward uterine lumen (Preisler et al., 2000). Results of present study with regard to $\mathrm{WBC}$, Lymphocyte and MCHC are also in accordance with the results of Coroian et al., (2017) who studied the biochemical and haematological blood parameters at different stages of lactation in cows. Significant $(p<0.05)$ decrease in lymphocyte on the day of calving as compared to $42 \mathrm{~d}$ pre-partum was seen in present study which might be due to cortisol associated suppression of lymphocyte. Granulocyte increased significantly $(p<0.05)$ on the day of calving when compared with $42 \mathrm{~d}$ pre-partum was seen in present study which might be due to increased number of neutrophils (Burton et al., 2005).

Level of RBC, $\mathrm{Hb}$ and PCV was significantly $(\mathrm{p}<0.05)$ higher in $\mathrm{T}_{3}$ as compared to both $\mathrm{T}_{1}$ and $\mathrm{T}_{2}$ groups throughout experiment period which was due to effect of mineral mixture supplementation (Gopinath et al., 2014). $\mathrm{MCV}$ and $\mathrm{MCH}$ levels differed significantly $(\mathrm{p}<0.05)$ among treatment groups throughout experimental period with minimum and maximum level observed in $T_{1}$ and $T_{3}$ group, respectively which also might be due to effect of mineral mixture supplementation.
Contrary to the present study Ate et al., (2009) observed that the mean values of PCV, $\mathrm{Hb}$ and $\mathrm{RBC}$ during third trimester of pregnancy and early lactation were nonsignificantly different. In present study there was significant difference $(p<0.05)$ in these hematological parameters between $42 \mathrm{~d}$ prepartum and early postpartum period. Platelet and granulocyte values of present study were higher and lower, respectively as compared to the study of Coroian et al., (2017) who studied the biochemical and haematological blood parameters at different stages of lactation in cows.

It may be concluded from the present study that WBC, Monocyte, $\mathrm{Hb}, \mathrm{PCV}, \mathrm{MCH}$ and MCHC were significantly $(\mathrm{p}<0.05)$ more in $\mathrm{T}_{3}$ as compared to $\mathrm{T}_{1}$ and $\mathrm{T}_{2}$ groups, whereas all the parameters except $\mathrm{MCV}$ and $\mathrm{MCH}$ in $\mathrm{T}_{1}$ and $\mathrm{T}_{2}$ group were at par which shows that modified feeding did not influence hematological profile. Although the health of animals was at par in all treatment groups, production and reproduction performance was different among the treatment groups.

\section{References}

Ate, I. U., Rekwot, P. I., Nok, A. J. \& Tekder, L. B. 2009. Haematological values of cows during third trimester of pregnancy and early lactation in settled cattle herds in Zaria, Northern Nigeria. Afr. J. Biomed. Res., 12(3): 225-231.

Burton, J. L., Madsen, Sally A., Chang, LingChu., Weber, Patty S. D., Buckham, Kelly R., Dorp, Renate Van, Hickey, Marry Clare. \& Earley, Bernadette. 2005. Gene expression signatures in neutrophils exposed to glucocorticoids: A new paradigm to help explain "neutrophil dysfunction" in parturient dairy cows. Vet. Immunol. Immunopathol., 105(3-4): 197-219.

Coroian, C. O., Mireşan, Vioara., Coroian, A., 
Răducu, C. Andronie, L. Marchiş, Z. Terheş, Sorin. \& Muntean, M. 2017. Biochemical and haematological blood parameters at different stages of lactation in cows. Bulletin UASVM Animal Science and Biotechnologies., 74(1): 31-36.

Gopinath, Devi., Sharma, M. C., Gurupriya, V. S. \& Singh, Mamta. 2014. Effect of mineral deficiency on major physiological and biochemical parameters in cattle in Idukki and Ernakuam districts of Kerala, India. Int. J. Agric. Sc \& Vet. Med., 2(3): 73-80.

Hussain, A. M. \& Daniel, R. C. W. 1992. Phagocytosis by uterine fluid and blood neutrophils and hematological changes in postpartum cows following normal and abnormal parturition. Therio., 37: 1253-1267.

Ingvartsen, K. L. 2006. Feeding- and management-related diseases in the transition cow - Physiological adaptations around calving and strategies to reduce feeding-related diseases. Animal Feed Science and Technology., 126: 175-213

Khaled, N. F., Illek, J. \& Gajdusek, S. 1999. Interactions between nutrition, blood metabolic profile and milk composition in dairy goats. Acta Vet. Brno., 68: 253258.

Khan, M. A. A., Islam, M. N., Khan, M. A. S. \& Akbar, M. A. 2004. Effects of feeding high and low energy levels during late pregnancy on performance of crossbred dairy cows and their calves. Asian-Aust. J. Anim. Sci., 17(7): 947-953.

Payne, J. M., Dew, S. M., Manston, R. I. \& Margaret, F. 1970. The use of a metabolic profile test in dairy herds. Veterinary Record., 87: 150-158.

Preisler, M. T., Weber, P. S., Tempelman, R. J., Erskine, R. J., Hunt, H. \& Burton, J. L. 2000. Glucocorticoid receptor down regulation in neutrophils of periparturient cows. Am. J. Vet. Res., 61: 14-19.

Roland, L., Drillich, M. \& Iwersen, M. 2014. Hematology as a diagnostic tool in bovine medicine. J. Vet. Diagn. Invest., 26(5): 592-598.

Singh, J., Singh, B. M., Wadhwa, M. \& Bakshi, M. P. S. 2003. Effect of level of feeding on the performance of crossbred cows during pre and post-partum periods. Asian-Aust. J. Anim. Sci., 16: 1749-1754.

Suharyono., Hardani, S. N. W., Sitoresmi, P. D. \& Adiarto. 2018. Effect of feed supplementation in Holstein Friesian crossbred cows at first quarter on the production and quality of milk. Paper presented at the IOP Conference Series: Earth and Environmental Science. 119: $1-12$.

\section{How to cite this article:}

Islam, M. M., S. V. Shah and Pathan, M. M. 2021. Effect of Different Feeding Regimes on Hematological Profile of Crossbred Cows. Int.J.Curr.Microbiol.App.Sci. 10(01): 2223-2229. doi: https://doi.org/10.20546/ijcmas.2021.1001.255 